\title{
Pacific Study Abroad Program's Impact on Students' Major and Career Choice
}

\author{
Rachel Bomser, Heather Gibson, \& Hongping Zhang \\ University of Florida
}

Faculty Mentor: Heather Gibson, Department of Tourism, Hospitality, \& Event Management

\begin{abstract}
Since 2007, the University of Florida has hosted summer field-based, sustainability-focused study abroad programs in Australia, New Zealand, and Fiji. The purpose of this quantitative study was to examine the impact of these study abroad programs on change of major and subsequent career choice. Program alumni (2007-2019) completed an online questionnaire. $\mathrm{N}=94$ responded to questions about impact on major, career choice, and open-ended responses. Data were analyzed using descriptive statistics, chi square, and content analysis. According to social learning theory of career decision-making, study abroad programs are among key factors that influence career choice. In this study, while some participants reported changing major, a higher number reported study abroad influenced their career choice. Content analysis revealed participation influenced some students to pursue a sustainability-focused career, work in "a helping-profession", pursue ecotourism, and study environmental law. Program participation seems to be influential for some in future career choice, but not major change.

Keywords: Study abroad, social learning theory of career decision-making, major, career choice, short-term study abroad, undergraduate
\end{abstract}

\section{Introduction}

Study abroad programs have become increasingly popular among college students over the past few decades. Close to 350,000 U.S. students studied abroad during the 2017-2018 academic year, according to the latest Open Doors study commissioned by the U.S. Department of State and implemented by the Institute of International Education (IIE). This demonstrates an increase of $2.7 \%$ over the previous year (IIE, 2020) and more than five times as many participants as 30 years ago, when just over 60,000 students studied abroad (IIE, 2002). While more students are opting to study overseas these days, the majority are choosing to participate in short-term programs (eight weeks or less), which account for $64.6 \%$ of all study abroad programs (IIE, 2020).

Much of the growth in study abroad programs may be due to a call by policy makers, researchers and practitioners to U.S. higher education to improve education abroad programs (Norris \& Gillespie, 2008). Norris and Gillespie suggested that: 
"Growing national bipartisanship support for international education such as the Lincoln Commission, a congressionally-appointed body whose members include leaders in the field, recognizes that education abroad has the unique ability to create global citizens who bring their intercultural knowledge into the work world, their communities, and their families (p. 2)."

With study abroad participation on the rise, multiple studies have been conducted to evaluate the personal and professional benefits these experiences provide to students (Black \& Duhon, 2006; Chapman, 2011; Dwyer \& Peters, 2004; Hadis, 2005; Kauffmann \& Kuh, 1984; Kronholz \& Osborn, 2016). Such personal benefits of study abroad participation include increased confidence, independence, and maturity (Franklin, 2010). Besides providing students with increased self-esteem and confidence, programs have been linked to influencing career choice (Orahood, Kruze \& Pearson, 2004). While the degree to which participants' career paths are impacted by education abroad varies by study, a majority of students report a positive influence (Norris \& Gillespie, 2008). In addition, in one study by Institute for the International Education of Students' (IES), 77\% of their 17,000 alumni indicated that they acquired skills that influenced their career path during their study abroad programs (Norris \& Gillespie, 2008). Using the Florida Downunder study abroad programs to Australia, New Zealand, and Fiji as a case study, the purpose of this study is to examine the impact of these programs on alumni's change in major and career choice, specifically long-term benefits and outcomes on career path (Florida Downunder, n.d.). To guide findings, four questions were presented:

1. Among the program participants, which majors were represented?

2. Did participation in study abroad impact change in major?

3. Is there a difference in program (Australia, New Zealand and Fiji) and impact on career choice?

4. What reasons were given for changing career?

\section{Literature Review}

A majority of current research on the effects of the study abroad experience examines impact on participants' personal and psychological development (Kronholz \& Osborn, 2016). A lesser known impact is in the development of career decision-making and vocational identity (Norris \& Gillespie, 2008; Orahood et al., 2004). To understand study abroad's influence on career choice, the social learning theory of career decision-making is utilized. This theory states that people 
acquire preferences for activities through varied learning experiences (Krumboltz \& Nichols, 1990).

Careers rarely follow a "simple, straightforward, and logical path", rather careers are influenced by a variety of situations and experiences (Orahood et al., 2004, p.119). Furthermore, social learning theory states that many factors interact to direct the individual down one career path or another, with both internal (personal) and external (environmental) factors determining how the person responds (Krumboltz \& Nichols, 1990).

According to the social learning theory of career decision-making, learning experiences, such as study abroad programs, are one of the key factors influencing career choice (Krumboltz, 1979;). Using social learning theory as a foundation of his study, Orahood found that students who studied abroad were more open to additional international experiences in their careers and tailored their job search to attain that goal. Their study revealed that $96 \%$ of respondents who had studied abroad said their experience made a difference in their career plans (Orahood et al., 2004).

This finding is further supported by the results of the IES' far-reaching study on the longterm impact of study abroad. In 2002, IES surveyed 17,000 alumni who had participated in its study abroad programs between 1950 and 1999. The IES 50-Year Alumni Survey examined how the study abroad experience affected the participants' academics, career choices, language abilities, and personal development (Norris \& Gillespie, 2008). The study revealed a significant impact on career path, with $62 \%$ of participants stating that their study abroad experience had influenced their career direction and $77 \%$ stating that through their study abroad program they acquired skills that influenced their career path (Norris \& Norris, 2005). Additionally, $48 \%$ of the survey respondents worked or volunteered in an international capacity at some point in their career (Norris \& Norris, 2005).

Several institution-based studies support these findings. A SAGE Research Project at the University of Minnesota, surveying more than 6,000 former study abroad participants from 22 different U.S. colleges and universities covering 50 years of alumni, discovered that $24 \%$ reported having an international dimension to their career and $35.2 \%$ declared that their career choice was largely influenced by their study abroad experience (Paige et al., 2008). In addition, a great majority $(71 \%)$ of respondents said their careers had been positively influenced by studying abroad (Norris \& Gillespie, 2008). Finally, a survey of previous ERASMUS exchange program 
participants with more than three years of career experience found that $63 \%$ of respondents believed their study abroad experience positively impacted their long-term career prospects (Potts, 2015).

In addition to influencing students' career path, research has shown that faculty-led study abroad programs promote student academic and career success (Ruth, Brewis, Blasco \& Wutich, 2019). Extensive research on the Erasmus Programme (a European Union student exchange program) found that participants had higher rates of employment as well as stronger work-related skills such as communication, language proficiency and adaptability (Brandenburg, Taboadela, Vancea et al., 2016).

Beyond researching how study abroad programs have positively impacted students' career choices, researchers have also looked into how these programs have affected the students' decision-making process and job satisfaction. A study by Kronholz and Osborn (2016) of alumni from a study abroad program at a large, public research university in the Southeast United States discovered that the study abroad experiences positively impacted students' career choice. This study found that $94 \%$ of students felt they had a better understanding of their interests, values, and skills in relation to making a career choice after participating in a study abroad program; $88.7 \%$ of students also thought more positively about career after studying abroad.

A study of alumni from the Dickinson College study abroad program found that $42 \%$ of survey participants strongly agreed or agreed that their study abroad experience influenced their career choice (Franklin, 2010). Additionally, the data revealed that the alumni who reported being strongly influenced by study abroad in career choice had the highest level of career satisfaction.

In addition to influencing career choice, study abroad programs have long been credited with providing students with the skills and traits needed to be successful personally. Numerous studies have demonstrated tangible benefits of study abroad in terms of increased self-confidence, independence, global competency, and open-mindedness, in addition to general personal growth and well-being (Black \& Duhon, 2006; Chapman, 2011; Dwyer \& Peters, 2004; Hadis, 2005; Kronholz \& Osborn, 2016; Kuh \& Kauffmann, 1984).

\section{Purpose of the Study}

The Florida Downunder study abroad programs are experiential field-based programs with a focus on sustainability to Australia, New Zealand, and Fiji. Since 2007, these short-term 
summer programs, ranging from ten days to five weeks, have been offered to University of Florida students. In Australia, the curriculum focuses on four modules: geography and history, indigenous culture, management of the rainforest, and management of the marine resources. In New Zealand, a similar four modular approach is taken to study natural resource management, adventure tourism, Maori culture and history, and sustainability. In Fiji, students learn about the natural, social, and economic aspects of natural resource conservation in Fiji, Fijian lifestyle, and ecotourism. Students are required to complete essays, an ethnography, scientific reports, and participate in group debates utilizing information learned from lectures, field trips, readings, and discussions with local residents.

The American Universities International Programs Limited, the parent company for The Florida Downunder programs, started faculty-led sustainability programs with partners in other land grant universities in the United States in 2005 (“AUIP”, n.d.). In 2006, UF was invited to join, and the first UF program started in 2007. A study based on the early days of these programs asked program participants to complete a pre- and post-program questionnaire (Bell, Gibson, Tarrant, Lane \& Stoner, 2014). Using open question format, 150 students were asked to reflect on how the program instigated change and how lessons learned abroad would transfer back in their lives at home. Bell et al. found that students reported a new sociocultural awareness, new connection with the natural world, appreciation for ecotourism and economic health, and a desire for positive change upon returning to their university. Of these changes, respondents from a range of majors (e.g., business, tourism, anthropology, political science, biology) indicated a desire to pursue an environmental career, educate themselves and others on the importance of sustainability and conservation, and changing habits to become more environmentally conscious. While this study provided insight into how these study abroad programs can impact participants, existing research has not focused on the long-term outcomes and benefits of these programs. Therefore, the purpose of this study is to examine the impact of these programs on alumni's change in major and career choice, specifically long-term benefits and outcomes on career path.

\section{Methods}

\section{Data Collection}

An online survey design was used to collect data from alumni of the Florida Downunder study abroad programs, from 2007 to 2019 . The study population was $\mathrm{N}=394$ former program participants. All were asked to participate in the study. The researchers initially contacted the 
participants via their university email addresses provided during program registration. While the University of Florida deactivates university emails after student graduation, many of the email addresses were still active when work began on this project in spring 2019. However, during Summer 2019, the University of Florida Alumni Association cleared the email registrar, which deactivated many email addresses. Fortunately, the email addresses for students from recent programs were still active. For students from earlier programs, we contacted former teaching assistants of the programs and asked them to post the survey link in the program's Facebook groups. The links were posted one to three times from October 2019 to January 2020. The protocol was reviewed by the Institutional Review Board at the University of Florida and approved prior to data collection.

\section{instrument.}

The instrument consisted of a fixed-choice and open-ended response format questionnaire that contained four sections.

Section one consists of a memory scale originally developed by Bluck and Alea (2011). The Cronbach's alpha' score for the memory scale is $\alpha .86$, showing good overall reliability (Bluck \& Alea, 2011). Items were measured using a 7-point Likert scale, ranging from never=1 to all the time=7. Questions were tailored to have participants reflect upon their study abroad experience.

Section two consists of items pertaining to pro-environmental behavior. The proenvironmental consumer behavior was assessed using the Ecologically Conscious Consumer Behavior Scale developed by Roberts (1991). This scale was adopted and tested by Tarrant, Rubin, and Stoner (2013) in a series of studies on study abroad. Reliability of the shortened (10item) Ecologically Conscious Consumer Behavior was tested (Cronbach's alpha = $\alpha .92)$ (Tarrant et al., 2014). An additional six questions measuring water use, coral reefs, and plastics were added as these topics were relevant to the study abroad program course content. All of the 16 items were measured on a 7-point Likert scale measuring behavior: never true $=1$ to always true $=7$.

Section three measured global citizenship utilizing a 7-point Likert scale ranging from Strongly Disagree $=1$ to Strongly Agree = 7. Morais' Global Citizenship questions (Morais, 2011) were utilized as a guide but edited to be more consistent and less overwhelming. Environmental attitudes were taken out and replaced by functions of memory to test the 
association between memory functions (self, social, and behavioral functions) and environmental behavior and global citizenship.

Section four measured demographic information including gender, year, program location, major, and career. An open-ended question was posed asking participants to indicate reasons they changed their career choice after the study abroad experience. For the current study, analysis focused on program, year, major, career, and the open-ended questions.

\section{Sample Description}

The study population was comprised of $\mathrm{N}=394$ previous participants of the Florida Downunder study abroad program from the years 2007 to 2019. $\mathrm{N}=101$ participants completed the survey, yielding a $20 \%$ response rate. Due to the incompletion of $n=7$ responses, analyses were based on $n=94$ responses. Of the participants in the sample who provided demographic information, $n=20$ were males and $n=67$ were females. Two participants responded 'other' in regard to their gender.

\section{Data Analysis}

Data were analyzed using Microsoft Excel for descriptive statistics and SPSS for chi-square analysis. The open-ended data were subjected to content analysis.

\section{Findings}

In measuring the impact of study abroad on major and career choice $n=94$ participants provided responses.

1. Among the program participants, which majors were represented?

Program participants were asked to identify their field of study for their bachelor's degree (Table 1). Of the $n=94$ respondents, $n=13$ indicated Business, $n=22$ Science, Technology, Engineering, and Math (STEM), n=18 Social Sciences, n=7 Sustainability related (sustainability, conservation, etc.), and n=19 selected Other. Participating STEM majors include Biology, Applied Physiology and Kinesiology, and Civil Engineering. Social Science majors include Psychology, Anthropology, and Political Science. A further $\mathrm{n}=12$ respondents identified variations of the Tourism, Recreation, and Sport Management (TRSM) hospitality degree programs offered at UF, such as Sport Management, Event Management, and Hospitality Management. Of the remaining respondents, $n=2$ identified as Advertising majors, while $n=1$ majored in Dietetics, $n=1$ in Elementary Education, $n=1$ in Graphic Design, $n=1$ in 
Telecommunications Production, $n=1$ in Economics, and n=1 in Marine Science. One participant did not answer this question.

Table 1. Majors Represented Among Participants

\begin{tabular}{lrcccc}
\hline Business & STEM & $\begin{array}{l}\text { Social } \\
\text { Sciences }\end{array}$ & Sustainability & TRSM & Other \\
\hline 13 & 23 & 19 & 18 & 12 & 8 \\
\hline
\end{tabular}

2. Did participation in study abroad impact change in major? (yes/no)

Of the $n=94$ respondents, $n=5$ reported changing their major after their participation in the study abroad program. Individuals stated that they changed their majors from Engineering to Plant Molecular Biology, Marketing to Political Science, and Health Science to Tourism \& Recreation. Two participants added a second major after participating in the study abroad program. One respondent added an International Studies (Europe) major in addition to Family, Youth, and Community Sciences. The fifth individual did not state their original major but noted that they added Sustainability Studies as a second major.

3. Is there a difference in program (Australia, New Zealand and Fiji) and impact on career choice?

Thirty nine of the 94 participants (41\%) reported study abroad influenced their career choice. A chi-square analysis revealed no significant relationship among the three programs in terms of career choice $(\mathrm{p}=.068)($ Table 2$)$.

Table 2. Study Abroad Impact on Career Choice

\begin{tabular}{lccc}
\hline & Value & df & Asymptotic Significance(two-sided) \\
\hline Pearson Chi-Square & $0.068^{\mathrm{a}}$ & 2 & 0.966 \\
Likelihood Ratio & 0.069 & 1 & 0.966 \\
Linear-by-Linear Association & 0.026 & 1 & 0.873 \\
N of Valid Cases & 92 & & \\
\hline
\end{tabular}

a. 0 cells $(0.0 \%)$ have expected count less than 5 . The minimum count is 5.37.

4. What reasons were given for changing careers?

Participants were given the opportunity to explain how the Florida Downunder programs influenced career choice (Table 3). When asked 'How did the program influence your career choice?', content analysis revealed participation influenced: $n=14$ to pursue a sustainability- 
focused career, $n=8$ to work in "a helping-profession", $n=6$ to pursue ecotourism, and $n=4$ to study environmental law. While every response varied, multiple phrases were commonly used throughout the responses. Participants who had chosen to pursue sustainability-focused careers noted wanting to "make a difference in communities," "reducing our carbon footprint with my coworkers," and desiring a "more hands-on career working with the environment." A few responses fell into multiple categories. For example, one participant noted that they felt encouraged by the program to pursue a career with sustainable events, which qualifies as a sustainability-focused career.

Table 3. Responses to open-ended questions about impact on career choice

\begin{tabular}{|c|c|c|c|}
\hline $\begin{array}{l}\text { To puruse a sustainability-focused } \\
\text { career }\end{array}$ & To work in "a helping profession" & To pursue ecotourism & To study environmental law \\
\hline $\begin{array}{l}\text {...after the program I realized I wanted } \\
\text { a more hands on career working with } \\
\text { the environment. }\end{array}$ & $\begin{array}{l}\text { It made me look at the bigger picture } \\
\text { and look for careers where I can help as } \\
\text { many people as possible. }\end{array}$ & $\begin{array}{l}\text { Yes, upon graduation, I started working } \\
\text { for an eco-friendly hotel as a manager. }\end{array}$ & $\begin{array}{l}\text { I am now in law school and I am } \\
\text { considering pursuing environmental } \\
\text { law. }\end{array}$ \\
\hline $\begin{array}{l}\text {...in the process of switching to working } \\
\text { for an environmental nonprofit... and } \\
\text { I'm sure my time abroad with UF } \\
\text { helped shape me into the person who } \\
\text { wants this new job! }\end{array}$ & $\begin{array}{l}\text { I wanted to be a study abroad advisor } \\
\text { and help others experience the joy of } \\
\text { international travel and give them the } \\
\text { opportunity to learn about other } \\
\text { cultures. }\end{array}$ & $\begin{array}{l}\text {...now I am an advocate for the planet } \\
\text { and strive to make an impact with my } \\
\text { career in the sustainable tourism } \\
\text { industry. }\end{array}$ & $\begin{array}{l}\text { I have now graduated from UF Law and } \\
\text { I specialized in environmental law. }\end{array}$ \\
\hline $\begin{array}{l}\text { It reminded me that a career in } \\
\text { sustainability is what I want. }\end{array}$ & $\begin{array}{l}\text { I also chose to go into recreational } \\
\text { sports because of the community } \\
\text { impact I can make versus if I had went } \\
\text { into professional sports. }\end{array}$ & $\begin{array}{l}\text { I am more interested in working in an } \\
\text { ecotourism organization. }\end{array}$ & $\begin{array}{l}\text { I am now going to law school to focus } \\
\text { on Environmental Law }\end{array}$ \\
\hline $\begin{array}{l}\text { I gained more of an interest in } \\
\text { sustainability and marketing, } \\
\text { marketing has gradually become my } \\
\text { top career choice in the sports industry }\end{array}$ & $\begin{array}{l}\text { Looking back, I believe this program } \\
\text { influenced my view of personal issues } \\
\text { to be on a broader scale and has } \\
\text { changed how I want to help people. }\end{array}$ & $\begin{array}{l}\text { I also traveled to Costa Rica to learn } \\
\text { Spanish and about the country and } \\
\text { their ideas about sustainability after } \\
\text { college. }\end{array}$ & $\begin{array}{l}\text { Previously, I wanted to do } \\
\text { environmental law, but after the } \\
\text { program I realized I wanted a more } \\
\text { hands on career working with the } \\
\text { environment. }\end{array}$ \\
\hline $\begin{array}{l}\text { I want to go to Australia and get a } \\
\text { working holiday visa and it furthered } \\
\text { my interest in marine conservation, } \\
\text { sustainability and cultural competence. }\end{array}$ & $\begin{array}{l}\text { With my major already being } \\
\text { Sustainability Studies, my optimal } \\
\text { career choice of influencing humans to } \\
\text { nurture the environment was } \\
\text { reinforced. }\end{array}$ & $\begin{array}{l}\text { Changed my minor/changed to a more } \\
\text { directly environmental career }\end{array}$ & \\
\hline $\begin{array}{l}\text { I know I want to travel abroad to teach } \\
\text { for a few years at the least. I also know } \\
\text { I want to be involved in global projects } \\
\text { that support sustainability. }\end{array}$ & $\begin{array}{l}\text { It helped make me want to specialize in } \\
\text { global health when I completed my } \\
\text { MPH program. I wanted a more global } \\
\text { perspective and a more lasting impact } \\
\text { rather than sticking to } 1 \text { aspect of public } \\
\text { health. }\end{array}$ & $\begin{array}{l}\text { I now want to study abroad in } \\
\text { Australia when I get older and do } \\
\text { more sustainable events. }\end{array}$ & \\
\hline
\end{tabular}


Table 3. (continued)

\begin{tabular}{|c|c|c|c|}
\hline To puruse a sustainability-focused career & |To work in "a helping profession" & To pursue ecotourism & To study environmental law \\
\hline $\begin{array}{l}\text { It solidified that I want to work in the } \\
\text { environmental/marine/sustainability field! }\end{array}$ & $\begin{array}{l}\text { I was already passionate about } \\
\text { sustainability but this program helped me } \\
\text { connect that to my passion for travel and } \\
\text { showed me how I can make a difference in } \\
\text { communities abroad by practicing } \\
\text { sustainable tourism. }\end{array}$ & & \\
\hline $\begin{array}{l}\text { I now want to study abroad in Australia } \\
\text { when I get older and do more sustainable } \\
\text { events. }\end{array}$ & $\begin{array}{l}\text { I also traveled to Costa Rica to learn Spanish } \\
\text { and about the country and their ideas about } \\
\text { sustainability after college. ... then moving } \\
\text { on to a job that is directly related to } \\
\text { sustainability. This program was a } \\
\text { necessary element in my career path and } \\
\text { personal development. }\end{array}$ & & \\
\hline \multicolumn{4}{|l|}{$\begin{array}{l}\text { It made me really passionate about } \\
\text { sustainability and finding the sustainable } \\
\text { way of doing things related to my career. }\end{array}$} \\
\hline \multicolumn{4}{|l|}{$\begin{array}{l}\text {...wanted to work for a company that took } \\
\text { steps to protect the environment. This was } \\
\text { something very important to me and I } \\
\text { frequently discuss reducing our carbon } \\
\text { footprint with my coworkers. }\end{array}$} \\
\hline \multicolumn{4}{|l|}{$\begin{array}{l}\text { Changed my minor/changed to a more } \\
\text { directly environmental career }\end{array}$} \\
\hline \multicolumn{4}{|l|}{$\begin{array}{l}\text { I went to grad school to study Sustainable } \\
\text { Development Practice. }\end{array}$} \\
\hline \multicolumn{4}{|l|}{$\begin{array}{l}\text { I went on to perform sustainability } \\
\text { audits/plans mirroring the program for a } \\
\text { church then took on two sustainability- } \\
\text { oriented internships. }\end{array}$} \\
\hline $\begin{array}{l}\text { The program encouraged me to use the } \\
\text { skills I will learn in my career and gear } \\
\text { them towards sustainable practices. }\end{array}$ & & & \\
\hline
\end{tabular}

\section{Discussion}

Social learning theory of career decision-making states that the interaction of many varying factors, including internal (personal) and external (environmental), directs an individual down one career path or another (Krumboltz \& Nichols, 1990). Thus, choice of major could be affected as it relates to career choice. Only five Florida Downunder participants indicated a change in major, including degrees more focused on either sustainability, tourism, or international studies, all of which are themes touched on during the program. While only a minority of participants changed their majors, these changes indicated a new path towards a specific career, one that may have changed due to participation in the study abroad program. 
According to the social learning theory of career decision-making, learning experiences, such as study abroad programs, are one of the key factors influencing career choice. Orahood, et al. (2004) found that $96 \%$ of respondents who had studied abroad said their experience made a difference in their career plans. Other research indicates that only $35.2 \%$ of participants felt that study abroad impacted their career choice (Paige et al., 2008). While the quantitative data show that the specific location of the Florida Downunder program did not have a significant relationship influencing the participants' career choice, almost half of the of participants reported that the study abroad experiences overall impacted career choice. However, information from the responses to the open-ended questions reveals a relationship between study abroad participation and career choice on a smaller scale with only a few students explaining how their career choices had been impacted. Nonetheless, overall this study finds that study abroad programs do have the ability to influence positive change among participants' career choice. Participants reported change in major and subsequent career choice to pursue more eco-friendly and sustainable industries or approaches to their chosen careers.

There are some limitations to this study that need to be recognized. Prior to designing the questionnaire, contact information for each of the programs' participants was collected and organized. Because the study abroad program is organized through the University of Florida, most students applied using their University of Florida email, ending in @ufl.edu. The sample was likely limited due to the University of Florida and University of Florida Alumni Association's decision to clear the registrar the summer prior to data collection. Therefore, the response rate is likely to have been affected, as lack of current contact information compromised access to the survey. However, in viewing the years of program participation and the gender breakdown, all programs are represented. In addition, the gender breakdown of more female than male participants was represented which is typical of participation in study abroad programs (IIE, 2020).

This study made some progress in understanding the relationship between study abroad programs, subsequent career choice, and social learning theory. Considering the increasing popularity of study abroad programs and possible impact on students' careers and personal lives, it is pertinent for research to continue. Given the potential to see a more defined relationship between study abroad programs and career choice, it is suggested that other types of programs be studied such as traditional, university-based programs or semester-long programs. 


\section{Acknowledgements}

I would like to express my appreciation to my faculty mentor, Heather Gibson, and her PhD student, Hongping Zhang, for their guidance and support throughout this process. This work could not have been possible without their expertise and input.

\section{References}

AUIP Faculty-led Flagship Sustainability Programs. (n.d.). Retrieved June 03, 2020, from https://auip.com/faculty-staff/flagship-programs/

Bell, H. L., Gibson, H. J., Tarrant, M.A., Perry III, L. G., Stoner, L. (2014). Transformational learning through study abroad: U.S. students' reflections on learning about sustainability in the South Pacific.” Leisure Studies, 35(4), 389-405. doi:10.1080/02614367.2014.962585

Black, H. T. \& Duhon, D. L. (2006). Assessing the impact of business study abroad programs on cultural awareness and personal development." Journal of Education for Business, 81(3), 140-144. doi:10.3200/joeb.81.3.140-144

Bluck, S. \& Alea, N. (2011). Crafting the TALE: Construction of a measure to assess the functions of autobiographical remembering. Memory, 19, 470-486. doi:10.1080/09658211.2011.590500

Brandenburg, U., Taboadela, O., Vancea, M. (2016). Mobility matters: the ERASMUS impact study. International Higher Education, 82, 116-120. doi:10.6017/ihe.2015.82.8863

Chapman, V. V. (2011). Beyond the "bubble:" study abroad and the psychosocial and career development of undergraduates." ProQuest Dissertations and Theses, 354. http://search.proquest.com/docview/879632035?accountid=4840

Dwyer, M. \& Peters, C. (2004). The benefits of study abroad. Transitions Abroad, 27, 56-57. https://www.transitionsabroad.com/publications/magazine/0403/benefits_study_abroad.shtml

Franklin, K. (2010). Long-term career impact and professional applicability of the study abroad experience. Frontiers: The Interdisciplinary Journal of Study Abroad, 19(Fall-Win), 169-190. https://files.eric.ed.gov/fulltext/EJ936414.pdf

Hadis, B. (2005). Why are they better students when they come back? Determinants of academic focusing gains in the study abroad experience. Frontiers: The Interdisciplinary Journal of Study Abroad, 11(1), pp. 57-70. doi:10.36366/frontiers.v11i1.151.

Institute of International Education. (2002). Fast Facts 2001. Open Doors Report on International Educational Exchange. Retrieved from file:///C:/Users/HPUser/Downloads/Fast-Facts2001\%20(3).pdf

Institute of International Education. (2020). Fast Facts 2019. Open Doors Report on International Educational Exchange. Retrieved from file:///C:/Users/HPUser/Downloads/Open Doors 2019 Fast Facts (3).pdf 
Kauffmann, N. L. \& Kuh, G. K. (1984, April). The impact of study abroad on personal development of college students. Paper presented at the annual meeting of the American Educational Research Association, New Orleans, Louisiana.

Kronholz, J. F. \& Osborn, D. S. (2016). The impact of study abroad experiences on vocational identity among college students. Frontiers: The Interdisciplinary Journal of Study Abroad, 27(April), 7084. Retrieved from https://files.eric.ed.gov/fulltext/EJ1099446.pdf

Krumboltz, J. D. (1996). A learning theory of career counseling. Handbook of Career Counseling Theory and Practice. pp. 55-80. doi: 10.1016/S0362-3319(97)90043-4

Krumboltz, J. D., \& Nichols, C. W. (2016). Integrating the Social Learning Theory of Career Decision Making. In W. B. Walsh \& S. H. Osipow (Authors), Career counseling: Contemporary topics in vocational psychology (pp. 159-170). New York: Routledge.

Norris, E. M., \& Gillespie, J. M. (2008). How study abroad shapes global careers: Evidence from the United States. Journal of Studies in International Education, 13(3), 382-397. doi:

$10.1177 / 1028315308319740$

Orahood, T. , Kruze, L., \& Pearson, D. E. (2004). The impact of study abroad on business students' career goals. Frontiers: The Interdisciplinary Journal of Study Abroad, 10(Fall), 117-130. doi: 10.36366/frontiers.v10i1.137

Paige, R. M., Fry, G. W., Stallman, E. M., Josic, J., Jon, J-E. (2009). Study abroad for global engagement: The long-term impact of mobility experiences. Intercultural Education, 20(suppl S12), 29-44. doi:10.1080/14675980903370847.

Potts, D. (2015). Understanding the early career benefits of learning abroad programs. Journal of Studies in International Education. 19(5), 443-356. doi: 10.1177/1028315315579241

Roberts, J. A. (1991). Development of a profile of the socially responsible consumer for the 1990s and its marketing management and public policy implications. ETD collection for University of Nebraska - Lincoln. AAI9200149.

Ruth, A., Brewis, A., Blasco, D., \& Wutich, A. (2019). Long-term benefits of short-term researchintegrated study abroad. Journal of Studies in International Education, 23(2), 265-280. doi: $10.1177 / 1028315318786448$

Tarrant, M. A., Lyons, K., Stoner, L., Kyle, G. T., Wearing, S., \& Poudyal, N. (2014). Global citizenry, educational travel and sustainable tourism: Evidence from Australia and New Zealand. Journal of Sustainable Tourism, 22(3), 403-420. doi: 10.1080/09669582.2013.815763

Tarrant, M. A., Rubin, D. L., Stoner, L. (2013). The added value of study abroad. Journal of Studies in International Education, 18(2), 141-161., doi:10.1177/1028315313497589. 